\title{
Ideology, Gender and Propaganda in the Soviet Union: A Historical Survey
}

\section{Choi Chatterjee}

In this paper I seek to resurrect the bugbear of Soviet history, the question of ideology. Until recently it appeared that the problem of Soviet ideology had died from sheer fatigue and been given a decent burial by the revisionist social historians. With the turn to social history, the focus of historians shifted from the primacy of politics and ideology in the Soviet Union to the social bases of Stalinism, and one rarely came across ideology as an analytical problem. Recently, however, a consideration of ideology has raised its hydra head impelled not only by those who seek to vindicate the totalitarian interpretation of Soviet history, but also by new theoretical approaches that have expanded the definition of ideology - of how it shapes identities, informs behaviour, and provides frameworks for interpreting experiences at both the individual and social level. ${ }^{1}$

I will not recapitulate the movement towards cultural history with its new emphasis on the importance of language and narratives, both spoken and written, elite and vernacular, in the construction and apprehension of experience. ${ }^{2}$ If language prefigures reality then we have no access to the past except through it, and rather than seeing language merely as a medium that conveys value-neutral information, we have to critically interrogate the literary genres, narrative structures, inflections of idiom, the complexities of reference, the self-representations and the anxieties woven into the texture of historical sources. Does this then make the historian a literary critic and/or a scholar of hermeneutics?

In this essay I propose to undertake a three-pronged analysis. First, I would like to trace the historical trajectory of the role of ideology in Western literature on the Soviet Union. Since this in itself is a lengthy undertaking I will focus on the works of a few seminal scholars such as Bertram Wolfe, Sheila Fitzpatrick and Stephen Kotkin. Then, I will survey a few key Western texts on the history of Soviet women and show how the authors have analyzed the role that ideology played both in conceptualization and the implementation of Soviet policies towards women. Finally, I will conclude with a few remarks on the gendered nature of Soviet ideology and propaganda.

\section{TOTALITARIANISM, REVISIONISM, AND IDEOLOGY}

Western Sovietologists used ideology in its instrumental capacity to explain all political innovations in the Soviet Union. In the totalitarian school of historiography, ideology was considered an important armament in the Bolshevik arsenal, and along with the use of terror, seen primarily as means of 


\section{Left History 6.2}

ensuring social obedience and control. ${ }^{3}$ Given the repressive nature of the state, it was commonly believed that there was little convergence between popular ideals and the state-mandated system of values. The Communist Party was accused of wanting to recreate both the individual and the world in its own image. According to Bertram Wolfe, one of the more astute commentators on the Soviet Union, "its aim is nothing less than to keep society atomized and to create as rapidly and as completely as the recalcitrant human material and the refractory surrounding world will permit, a new man, a new society, and a new world."4

While this utopian impulse has an invidious connotation in the context of political liberalism as an infringement on the rights of the individual, according to Marxist thought, ideology becomes praxis or meaningful activity only when it is aimed at transforming the world. However, this explanation was subsumed by more sinister interpretations that emphasized the Bolsheviks' quest for total power. Moreover, since the Bolsheviks consciously acted as kulturtraegers, making little attempt to conceal the extent, form, and nature of their "civilizing mission," the values they sought to inculcate were seen interchangeably as ideology and propaganda by the outside world. ${ }^{5}$ Sovietologists commonly referred to the Soviet Union as an ideological state, implying that its very dedication to ideology represented an aberration from the normal evolution of nation-states. "To a far greater extent than most political systems, the Soviet system is the creation of a consciously articulated body of ideas - the ideology."6

Wolfe saw the Bolshevik revolution primarily as a result of Lenin's ruthless drive for power. Again, I quote, "the basic ideology of MarxismLeninism is structural in character. Organization, centralization, monopoly of economic power and spiritual power, permanent dictatorship, force unrestricted by anything - these were the substances of Lenin's dreams from 1902 onwards."7 Lenin's faith in his own theoretical insights led him to a grotesque distortion of Marxism, and in Wolfe's account we see the Bolshevik revolution unfold on a stage bereft of actors and driven solely by the power of Lenin's maniacal ideas. Although Wolfe never states his definition of ideology, it is clear from his account that he views Leninism as a succinct guide to action, a blueprint for transforming or shaping the world.

Other historians from the totalitarian school reiterated this basic tenet and viewed Marxism-Leninism as a means of legitimizing relations of domination and upholding social hierarchies in the Soviet Union. Soviet ideology was seen as little more than a set of utopian dogmas imposed on a sullen population. Even Robert Daniels, who distanced himself considerably from the older interpretations by claiming that the October Revolution was more an accident than a planned coup, nevertheless concluded that Stalinist ideology divested itself of its Marxist intellectual content to more effectively drown both the individual and society in sea of false consciousness. ${ }^{8}$ Indeed, according to 
Daniels, Marxism-Leninism was used merely to legitimize programs that had been adopted for other practical reasons.

Martin Malia is an original voice in this field in that he insists that it is impossible to understand the Soviet revolution without the grand idea of socialism, its commitment to social equality through the abolition of the market, private property, and the state control of economy. Indeed Malia is also unique in that he tries to explain the underlying ethical motivation that provided the justification for using coercion on an unimaginable scale. ${ }^{9}$

Two things need to be pointed out in this historiographic context. First, these historians have used a very rigidly Marxist definition of ideology. In German Ideology, criticizing religious and metaphysical ideas that convey a false impression of the world, Marx and Engels wrote, "if in all ideology men and their circumstances appear upside down as in a camera obscura, this phenomenon arises just as much from their historical life-process as the inversion of objects in the retina does from their physical life-process." 10 According to Marx, in any given historical epoch, the prevalent ideas are usually those produced by the dominant class or those that express their aspirations and interests. At the same time, these ideas are held up as having universal validity and significance. This produces a false consciousness that masks the class conflicts in society while legitimizing the domination of the ruling class. Although few historians from the totalitarian school attempted a class analysis of Soviet society, they nonetheless viewed Marxist-Leninist ideology as a means through which the Party/nomenklatura dominated the Soviet people and induced acquiescence among the population to the regime's terroristic policies.

But as Karl Mannheim has shown, not all ideologies are geared towards conscious deception. In fact most historical epochs contain ideas that transcend the existing order, but as long as they do not succeed in realizing their projected contents they can be called ideologies of the age. Utopias on the other hand are wish-dreams that aim at the transformation of societies. Mannheim also argues that it is only in retrospect that one can distinguish between the ideological and the utopian, as these do not occur separately in a historical process. The designation of what is utopian or ideological depends to a large degree on the social position of the observer as the utopias of an ascendant class are often permeated with the ideological elements and the difference between the two can only be verified by historical process. ${ }^{11}$

Bolshevik ideology was unique in that it tried to encode the utopian, serving both as a means of social control and fuel for revolutionary experimentation and radical change. And this was especially true in the Stalinist period when state sponsored policies promoted maximum social disruption as well as the social conservatism of the "Great Retreat."12 Although Richard Stites has commented on the decline of "social day-dreaming" with the advent of Stalin and the imposition of a single administrative utopia, this 


\section{Left History 6.2}

was not necessarily the case. Rather, there was a replacement of utopian ideals of a certain section of the avant-garde intelligentsia with a complex of other competing utopian discourses that constituted Stalinism. Ideals of a welfare state, the aspirations to a super power status in the world order, the attempts to institute socialist realism in both art and life, and even the creation of legions of modern Soviet heroes and heroines cannot easily be accommodated under the rubric of the "anti-utopian utopian state" that Stites has described. ${ }^{13}$

Subsequently, with the turn to social history, under the auspices of Sheila Fitzpatrick's pioneering work, historians presented a new and dynamic model of Soviet society that encapsulated both the use of terror and popular participation, and represented the Bolshevik revolution as a conduit of social mobility for the young and the ambitious. Perhaps, as a reaction to the totalitarian model's obsession with Bolshevik propaganda, these historians sought to downplay the role of ideology as a primus casus in Soviet society. While Fitzpatrick, Viola and Chase explained the capacity of Stalinist rhetoric to exhort and motivate young Bolshevik cadres, Bolshevik-speak itself was not subjected to detailed scrutiny. ${ }^{14}$

Fitzpatrick's work, given its exhaustive sweep and analytical grandeur is difficult to summarize. According to her, the Stalinist state was relentless in its antipathy to capitalism and was committed to building socialism by destroying private enterprise, and promoting economic growth and modernization through state planning. Fitzpatrick argues that Bolsheviks never lost their ideological adherence to a certain variant of Marxism, nonetheless she shows that their analytical approach was highly creative and pragmatic especially when it came to the issue of class. While the Bolsheviks continued to use a class analysis in interpreting Soviet material reality and, in fact, legitimized their power as the vanguard of the working class, the definitions of who constituted the proletariat changed according to new political situations and calculations.

The classical bourgeoisie and aristocracy, stock characters in the Marxist morality play, were replaced by the professional intelligentsia, and later the kulaks, as the class enemy. This was despite the fact that the bourgeois specialists held a privileged position in Soviet society until 1929 and recovered much of their status in the aftermath of the Purges. More problematic for the Bolsheviks was the definition of what constituted the working class. Especially since the worker base of the party was seriously eroded during the Civil War while the number of intelligentsia dominating both the Party and the economy grew proportionately. A compromise was reached by increasing worker representation in the administration and restricting the definition of proletarian to those with a factory affiliation in 1917 or at the time of entry to the party. Later, in the 1930s, as millions of peasants entered the ranks of the working class, the definition of proletarian consciousness was expanded to mean enthusiastic support for the construction of socialism and political loyalty. 
Ultimately, the bourgeois specialists were physically replaced by Stalinist cadres of proletarian/peasant intelligentsia who came to dominate the Soviet Union politically.

Soviet citizens for their part used the ideological definitions provided by the state to articulate their identities, construct life histories, denounce personal enemies, and even legitimize subversion and resistance as acts of political loyalty. ${ }^{15}$ What remains unclear in the narrative, however, is the true role of ideology in Stalinist calculations. Did the regime's ideological assumptions dictate policies such as the class warfare of the Cultural Revolution and the Great Purges or was the repeated ideological revisionism of class definitions a post hoc rationalization of unintended consequences?

Recently, Stephen Kotkin, in his provocative study of the "Soviet civilization," has brought to the forefront the role propaganda and ideology played in the construction of Soviet identities and Soviet realities. ${ }^{16}$ "Bolshevism itself, including its evolution, must be seen not merely as a set of institutions, a group of personalities, or as an ideology but as a cluster of powerful symbols and attitudes, a language and new forms of speech, new ways of behaving in public and private, even new styles of dress - in short, as an ongoing experience through which it was possible to imagine and strive to bring about a new civilization called socialism."17

Kotkin has radically expanded the concept of ideology from the totalitarian definition of a political blueprint to something akin to an anthropological definition of culture as elaborated by Clifford Geertz. ${ }^{18}$ The term ideology can be used in both a restrictive manner as a specific set of beliefs, or as something more inchoate that colours our beliefs and structures social practices. According to Althusser, ideology is not merely a distorted representation of real social relations, but a means through which human beings live their relation to their world and reproduce the conditions of their existence. Ideology has a material existence as expressed through social practices and rituals. ${ }^{19}$ Thus in Kotkin's account we see the inhabitants of Magnitogorsk struggling to speak Bolshevik, and, given the lack of other competing discourses, articulating their identities in the intellectual categories that the Party makes available. While Soviet citizens adapted their behavior to the prevailing ecosystem they in turn helped to shape it.

Kotkin also refuses to see in Stalinism, the revolution betrayed. Instead he views certain concepts as fundamental and integral to the Bolshevik mental architecture that span the continuum of Stalinism. One is the notion of the progressive and modern welfare state, the other the rejection of the inequities of capitalism. Finally, Kotkin sees in the existence of a hostile and immoral capitalist world, the raison d'être and staying power of Stalinism. In fact Kotkin uses the continual viability of these concepts to counter critics who allege that under Stalin "ideological" considerations were subsumed by "practical" ones. ${ }^{20}$ Kotkin dismisses the revival of chauvinistic nationalism, 
growing conservatism towards family issues, and the crackdown on abortion as mere policy shifts rather than an abandonment of the revolutionary idealism. But as these so-called "policy shifts" are not analyzed in any great detail it seems more an assertion than a serious engagement with the "Great Retreat" thesis. Moreover, at one level while Kotkin appears to argue that Bolshevik ideology was elastic, fluid, and created in part by the engagement of both the state and the people, on another, he represents ideology as a set of unchanging moral choices and a certain worldview that the Stalinist state adhered to and managed to inculcate in its people.

Finally, the concepts that Kotkin has used as the central premises of his monograph, the notion of social justice, the evolution of a welfare state, the negative representations of capitalism and by extension the West were not static symbols and categories. In public propaganda these were constantly being constructed and re-constructed. And as Moshe Lewin has shown, the syncretism of Stalinist ideology and its ability to import a variety of ideas, rituals, myths and symbols that were antithetical to Marxism gave it both its resilience and uniqueness. ${ }^{21}$ In the final analysis, what might have held Bolshevik ideology together was perhaps less the purity of its central tenets, than the literary conventions and stylistic repetitions which imposed on its many dissonances a seeming uniformity. ${ }^{22}$

\section{IDEOLOGY AND WOMEN'S HISTORY 23}

In an introduction to a study, Frederic Jameson referred to its "organizational fiction," the textual strategy of a work that sets out to resolve a problem that the author creates in the first place. ${ }^{24}$ Soviet historiography seems replete with organizational fictions, as reflected in titles of monographs, such as Reshenie zhenskogo voprosa, Opyt KPSS v reshenie zhenskogo voprosa. During the Soviet era perceived social and political problems of Soviet society were indiscriminately quantified and represented as circumscribed and selflimiting phenomena, which would succumb to a concerted socialist offensive (nastuplenie). The successful conclusion of these campaigns was a foregone conclusion, as the problem was usually posed in terms of its ultimate resolution.

In western historiography too, we have our organizational fictions that curiously mirror Soviet counterparts. Thus for example a disproportionate share of our scholarship is concerned with disproving Soviet claims about their achievements in the field of women's liberation, or exposing the "truth" of awful misogyny that lay behind Soviet assertions of having attained gender parity. Like their Soviet counterparts, western historians have accepted the notion of a "zhenskii vopros" (woman question) as a self-contained social problem that could either be resolved or shelved through resolute action undertaken by the Party.

Unlike the more contradictory attitudes exhibited towards the principles of 
Marxism by academics, by and large historians have enthusiastically endorsed the basic premises of Marxist feminism, that is the incorporation of women into wage labour, the democratization of the patriarchal family, the communalization of housework, and the elimination of gender disparity in the private and public sphere. What then annoys these historians is the failure of the Soviet Union to institute any of these goals in a meaningful fashion. Thus Aleksandra Kollontai's story is usually told in tragic mode of a visionary who ran into the shoals of Bolshevik misogyny and conservatism while trying to advance a radical feminist agenda that was ahead of its time..$^{25}$

Other histories plot the decline of the Soviet regime's commitment to feminism from the heyday of the Civil War to the reactionary nightmare of the 1930s. We are unsure as to when the rot set in, was it the Civil War, the NEP, the First Five-Year Plan? Recently, Wendy Goldman has written a provocative book in which she attributes the failure of the Bolsheviks to recreate the patriarchal family along democratic lines to the innate conservatism of Russian women rather than to the traditional values espoused by the policy makers. ${ }^{26}$ She points to the economic factors that made it impossible for the Zhenotdel to establish childcare institutions and other communal services. At the same time she shows that both proletarian and peasant women felt that it was impossible to raise families in the grim economic climate of the 1920s without the contribution of fathers and husbands. Both Beatrice Farnsworth and Barbara Clements agree with Goldman that the Bolsheviks adopted a more traditional social policy in the 1920s towards the family. Ultimately it was easier and cheaper to shore up the traditional nuclear family, rather than create a true welfare state that would assume responsibility for all Soviet children. But unlike Goldman, these two scholars privilege ideological conservatism as the main determinant of state policy rather than the actions of Russian women themselves. ${ }^{27}$

Elizabeth Wood too has foregrounded the issue of ideology by showing that Bolshevik ideas on women's liberation did not change significantly in the $1920 \mathrm{~s}^{28}$ Instead, she argues that at inception, these ideas were artificially grafted onto underlying nineteenth-century Russian attitudes of misogynous disdain towards women, ones in which they were perceived primarily as backward, uncultured mothers who needed male tutelage. It was the uneasy coexistence of a commitment to draw women into the public sphere coupled with an innate hostility to anything that smacked of feminism that gave Bolshevik ideology its ambiguous and tense character. According to Wood these narratives of backwardness went a long way in perpetuating Bolshevik hostility and indifference to women's issues even though the debates about gender allowed the Bolsheviks significant power to shape family life and intimate private relationships. Traditional gender connotations were retained even while the Bolsheviks professed that they were turning the "baba" into a "comrade," and women were exhorted to be mothers to the society at large. 


\section{Left History 6.2}

Others scholars such as Bonnell, Waters, and Bernstein, in their work on representations of women in public iconography, tend to read female icons as either superfluous or even inimical to the revolution. Positive models such as the kolkhoznitsa were usually considered unrepresentative of reality, and eventually subordinated to the male counterparts who were overwhelmingly chosen to personify the important processes and events in Bolshevik history. ${ }^{29}$ According to a recent article on representations of gender in Soviet art of the late 1930s, Susan Reid claims that "the audience for images directly promoting the Stalin cult was imagined as female, and spectatorship was construed as an act of 'feminine' identification and submission." 30 In this article one reads feminine as passive, slavish, uncritical and gullible. Finally, there seems to be a near consensus that Stalinism represented the nadir of the women's position in the Soviet Union. While the state claimed to have achieved the liberation of women in a flood of self-serving propaganda, in reality all affirmative action policies were abandoned as women were turned into workhorses-cum-brood mares. The patriarchal family, renamed as socialist, was glorified, divorce became difficult to obtain, abortion was declared illegal, and women were exhorted to both produce and reproduce for the sake of the nation. ${ }^{31}$

Of course there are a few exceptions to this line of argument and both Sheila Fitzpatrick and Roberta Manning have claimed that in the countryside the state was committed to policies that were aimed at liberating rural women from patriarchal domination and enrolling them in non-traditional pursuits. ${ }^{32}$ And Richard Stites struck a more optimistic note when he asserted that a commitment to women's emancipation survived the Thermidor imposed by Stalin and resurfaced as one of the more enduring strands of Soviet ideology. ${ }^{33}$

It is interesting that the debate is polarized primarily in moral terms, on the axis of liberation versus conservatism. I believe that this is due primarily to the influence of liberal-feminism, an ideology that views woman as a unitary subject, with legally defined rights and obligations whose emancipation can be plotted precisely on a graph. Also the notion that a regime must be accountable to its own rhetoric pervades much of the western critique of the Bolshevik regime. Presumably if the Bolsheviks had not advanced an agenda of liberation they would not be held accountable to fulfilling it.

In a recent monograph, Nancy Ries has argued that while some cultures locate value in distinctive consumerism, or ritual participation, Russians privilege language above all other things, and see it as one of their most valuable resources. ${ }^{34}$ Historians have blamed the Soviets for failing to solve the "woman question" and criticized the hypocrisy that underlay the pervasive revolutionary rhetoric about gender equality. But the non-correspondence of ideology and reality constituted an important element of the Soviet experience. Soviet propaganda for women was characterized by a literary style that was marked by what we read as excess, exaggeration, falsifications, distortions, embellishment, fantasy and over-statements. Our liberal orientation may lead 
us to denounce a style of political narration that lacks material accountability, but one should not discount the importance of changes at the ideological and linguistic level. The capacity to imagine and articulate scenarios of radical change in women's lives was not a substitute for concrete action, but was in itself an act of power and a form of political practice.

Rather than focus on those aspects of women's liberation that seem the closest or farthest to our political convictions one can decipher alternative patterns in Bolshevik ideology and propaganda. Although Bolshevik ideology for women aspired to create a set of enduring myths about the "New Soviet Woman," the exigencies of the revolutionary situation tended to destabilize gendered identities. As a result the public selfhood of Soviet women was constantly mediated by competing definitions of class, occupation, sex, family, community, citizenship, party and state. Female identity in the Soviet Union was constructed as a continuum, composed of various building blocks or ideograms. ${ }^{35}$ These ideograms or sound bites were deeply symbolic and functioned as a convenient shorthand to more complex philosophical assumptions. Ideograms could be re-arranged to suit the demands of the current political situation or could be reinforced by the importation of new ones. At the linguistic level, ideological innovations could be rendered mundane, while continuity could be represented as revolutionary. Rather than seeing a strict disjuncture between the ideological radicalism of the early years and the conservatism of the 1930s, I would argue that there was considerable continuity of certain patterns of discourse pertaining to women that cannot be easily classified under the moral polarization of emancipatory or reactionary.

Although Bolshevik thinking about the "woman question," was grounded in classical Marxism and Social-Democratic thought, public propaganda took selectively and creatively from this philosophical bedrock, emphasizing different aspects at various historical moments and periods. Engels, in his The Origin of the Family, Private Property and the State, asserted that the status of women was determined by the prevailing mode of production and its attendant property relations. ${ }^{36}$ Borrowing heavily from the works of anthropologists, Engels argued that the origin of patriarchy was rooted in the creation of private property. Despite the dubious merits of this argument, by historicizing the family, Engels brought into question the validity of the "innate" and "natural" functions of women that patriarchal discourse ascribed to them. ${ }^{37}$

The other contribution of Marxism was to implicate capitalism and patriarchy in the oppression of women thus holding that the "woman question" could only exist in a capitalist society. If capitalism itself, by the laws of historical materialism, was doomed to extinction, so too was the cultural superstructure of capitalism that perpetuated the subordination of women. In the post-capitalist society women would be important primarily as units of labour. The Bolsheviks exhibited none of the ambiguity or Victorian reservations that Engels had about the use of women in factory production but 


\section{Left History 6.2}

took very literally the second part of the Marxist dicta about the contribution of each according to his abilities. The Constitution that was adopted in 1918 mandated labour as the primary duty of all citizens. And as Stalin said very succinctly, "it is not property status, not national origin, not sex, nor office, but personal ability and personal labor that determines the position of every citizen in society." 38

Continuing with the metaphor of productive labour were the twin issues of reproduction and domestic labour. Was the act of biological reproduction socially useful labour? It was Kollontai, the arch-feminist, who argued that as reproduction ultimately guaranteed the existence of the labour republic, the state should facilitate motherhood by providing ideal conditions for it. ${ }^{39}$ This argument received great prominence in the 1930 s when biological reproduction was valorized as socially useful and necessary. On the issue of domestic labour, Marxists were unanimous in their condemnation of women's exclusive engagement in household tasks. ${ }^{40}$ August Bebel, in his widely read work, Women under Socialism, painted a romantic picture of a post-socialist society where the bourgeois family would be redefined. Communal organizations would take on the tasks of cooking, cleaning, washing and childcare. ${ }^{41}$

This was the essential contradiction of Marxism, on the one hand it envisaged the disappearance of the bourgeois state, and on the other, it foretold an enormous increase in the functions and power of the socialist state. Bolsheviks believed that the state should protect the rights of women and children, ensure that women had access to education, relieve women from the onus of domesticity, and promote them to positions of power and authority. The modern vision of both the affirmative action welfare state and the omnicompetent state therefore, derived from Marxist thinking and Soviet practice. ${ }^{42}$

At the same time, given the material poverty of the country in the 1920s, political theorists were de-emphasizing the role of the state in women's emancipation and stressing the importance of grassroots activism. ${ }^{43}$ Leaders of the Party such as Lenin and Trotsky, and organizations such as the trade unions, subscribed to a notion of popular participation in officially sponsored "women's issues." ${ }^{4}$ Thus women were encouraged to set up sewing artels, poultry farms, co-operative daycare centers, and communal kitchens. The emphasis on improvisation, resilience, and magical female ability to sustain meaningful life and community in the middle of social dislocations and male incompetence was an important part of Bolshevik discourse.

Where did men fit into this scenario of the state and women? If one reads the Marxist texts about conscious women one is struck by the progressive displacement of the male to the margins both figuratively and literally. Analyzing Engels' work, The Origin of the Family, Private Property and the State, Alfred Meyer commented thus: "throughout the book, Engels conveys the impression that matriarchy was preferable to male domination and that it 
corresponded to a nobler and more humane way of life. Matriarchy reigned in a communistic, propertyless community blessed with equality, sexual freedom, general self-respect, and respect for others." 45 While Bolsheviks never endorsed matriarchy as a political principle, in propaganda men were often represented as a hindrance that disrupted the social intercourse of the state and politically conscious women. Kollontai's fiction is replete with the symbolic erasure of men and the arbitrary silencing of their voices. As her stories progress, while her heroines grow stronger, men usually display a distressing capacity for degeneration, both moral and ideological. ${ }^{46}$ And in this instance the class affiliations of the anti-heroes is less important than their gender, as men of both proletarian and bourgeois origin seem susceptible to the pleasures of the flesh. And even during the years of Stalinist conservatism it was very common to find the symbolic dismemberment of male supremacy in stories about Stalinist heroines.

But it is important to remember that Bolshevik ire was reserved for the local, the consanguinal male. There was no attempt to dismantle patriarchy per se, but an effort was made to replace the authority of the local male, of fathers, brothers, and husbands, with that of the absent, omnipotent, male of socialist patriarchy. This trend started with the veneration of the dead Lenin and other communist leaders and found its apotheosis in the cult of Stalin. The conflation of the image of the nation and the dictator did not lead to the strengthening of the father figure in the family as in fascist states. But because of the conjoining of socialist patriarchal discourse with modern narratives of female emancipation, it led to the symbolic emasculation of the authority of the local male, while valorizing women's capacity to improvise, sustain and survive.

There were other essential criteria that constituted the lineaments of the female self in Bolshevik representations. One was the motif of backwardness, and the other, the situational identity of women. Marxist canonical writings on women contained several imaginative denunciations of unreconstructed Russian women and by extension of their femininity. ${ }^{47}$ But backwardness, conservatism, disinclination to action, was not considered as innately feminine characteristics, but a product of women's tragic past. For a party that claimed to be the vanguard of the future, the Bolsheviks were disproportionately obsessed with history in its dramatic capacity to provide a foil to the achievements of the revolution. And women's history was invariably narrated in the tragic mode familiar to those steeped in the literary traditions of Turgenev, Tolstoy, and Nekrasov. In the Bolshevik version, however, suffering was neither ennobling nor an inevitable mark of gender. Rather, women's suffering stemmed from a lack of understanding about the true reasons for their misfortune. As a result women privileged family over class, the domestic space over the social realm, and passivity over revolution.

If women were to be partners in the revolution, they would have to shed the guise of Russian femininity and take on the persona of Bolshevik women: 


\section{Left History 6.2}

their tverdost', their dedication to revolution, and their immense capacity for personal heroism and self-sacrifice. ${ }^{48}$ Bolshevik propaganda in the period under review, unlike liberalism, never used arguments from nature to reify women's basic incapacity to act as competent citizens in the public sphere. Instead the core tenet of Bolshevism rested on the assumption that the cultural reconstruction of women was possible as long as women made the choice to internalize the prescriptive mores and values inherent in Bolshevik propaganda. Bolshevism therefore was both a call to arms and a prescription for self-regeneration. ${ }^{49}$

As is clear from the preceding section, the notion of the female comrade as articulated in Bolshevik propaganda was not the unencumbered self of liberal theory, the bearer of inviolable and individual rights. Rather, it was the situated self or the communitarian self, whose identity was located in the intersection of the obligations of social justice, the commonweal, and the Party. A woman's identity was imagined in terms of her relationship to the family, children, community, and state, but not necessarily in that order.

Finally, and most importantly, the Bolsheviks used the status of women under Soviet rule as a way to prove their modernity and their vanguard position among the European nations. ${ }^{50}$ Lenin claimed in 1919 that, "the position of women furnishes a particularly graphic elucidation of the difference between bourgeois and socialist democracy ... in no bourgeois republic ... nowhere in the world, not even in the most advanced country, have women gained a position of complete equality." 51 The veracity of the statement was far less important than the emergence of a particular style of discourse in which women functioned as a marker or an index of progressiveness.

\section{TOWARDS A CONCLUSION}

According to Ricouer, ideology is a positive phenomenon, "expressing the necessity for any group to give itself an image of itself, to fill the gap between its origin and its actuality, its founding project and its fading collective memory." 52 Bolshevik ideology in this context was an attempt by a ruling class to make order out of chaos, to reduce the overwhelming flood of raw reality into accessible categories, and ultimately to reproduce the internal selfunderstanding of a dominant group. ${ }^{53}$ Bolshevik ideology was essentially performative rather than descriptive, programmatic rather than pragmatic, and therefore, extravagant and inconsistent.

Soviet propaganda, the actual articulation of ideology, served a variety of functions. Ideology provided a generative frame of reference that both governed the production of this new genre and its interpretation. Propaganda was integral to the formation of a peculiarly Soviet identity. The literary strategies used to construct Soviet-speak are an important contribution to the categories of public speech, and thus deserve a hermeneutical analysis as a literary form. Party members, bureaucrats, exemplary school children, Soviet 
heroines, all those who participated in the Soviet public sphere, operated within the intellectual world of propaganda. As a means of communication, Soviet-speak was cumbersome, repetitive, and over-laden with jargon. At the same time it was simple to master, and the ideology was so elastic that even those unacquainted with Marxist theory could comfortably converse within its perimeters. The important question is not whether the people believed it or even internalized it, but the fact that they articulated, repeated and perpetuated the categories of a Soviet weltanschauung, creating a space in which every Soviet citizen could participate, and cue into. Soviet-speak was perhaps one of the most unifying and stabilizing forces in the Soviet Union, and Soviet identity was fundamentally related to the mastery of this body of coded phrases.

The present debate on affirmative action in the United States serves as an example. Although people might not really believe in the politics of gender and racial parity, they are afraid to voice a public criticism because of the moral stance that feminist- and minority-politics has taken. Similarly, in the Soviet Union, although the exaggerated rhetoric about solving the "woman question" did not directly translate into improved living standards or the diminution of misogynistic attitudes, in the world of public utterances, the Soviets were loath to utter sentiments that might be construed as anti-women. Soviet propaganda, therefore, became a means of self-censorship, much like the category of "political correctness" in the United States today.

Second, the rhetoric about women in the Soviet Union served as a means of legitimization for the regime. Soviet identity was created against an imagined European identity, both liberal and fascist. Soviet accomplishments were repeatedly contrasted with the deficiencies, shortcomings and limitations of a more "advanced" Western Europe. In this dialogue, the "New Soviet Woman" served as the embodiment of Soviet belief in gender equality and state welfare policies. Although the Soviet Union did not create a truly efficient system of childcare, or communal institutions that would take over the domestic tasks that women traditionally performed, it was a goal that the Soviet Union publicly adhered to.

The idea of a welfare state responsive to women's needs was a novel innovation in politics, especially compared to the Western world in the $1920 \mathrm{~s}$ and 1930s, where welfare policies were often seen as a temporary and charitable gesture towards distressed citizens. More commonly, in the West, welfare measures were intended to strengthen the patriarchal family and keep women out of the waged labour market. ${ }^{54}$ In a sense, by acknowledging the rights of citizens, the state was exposing itself to criticism for the nonfulfillment of its obligations. Although the Soviet women lacked the power to force the state to meet its self-proclaimed obligations, Soviet propaganda provided citizens with a yardstick against which they could measure the various deficiencies of the system. Therefore, in an unforeseen way, 


\section{Left History 6.2}

propaganda could serve as a means of empowerment for the masses by providing a permissible vocabulary of complaint and criticism.

Third, the model of the "New Soviet Woman" also served as a justification of the creative and innovative nature of the October Revolution. It was not mere happenstance that the propaganda surrounding both the Lenin and Stalin cults repeatedly emphasized the leaders' care for that politically backward cohort, women. But in the separate models of the "New Soviet Woman" that each period spawned one could gauge the difference between the Lenin and the Stalin cult. In the 1920s, the popular fictions of female destinies were personified in the imaginary denizens of a communist future, or in the pages of literature. Apart from the old Bolshevik female leaders, there were few memorable heroines of the NEP era. Those with claims to fame usually used their valorous participation in the Civil War to signify their importance to the revolution.

In the 1930 s by contrast, Stalinist propaganda did not dwell on the process of achievement of feminist goals, but merely reiterated its end results in exaggerated terms. Under Stalin, the material conditions had changed so dramatically, or so it was claimed in the propaganda, that Soviet heroines (modern women) were to be found in every corner of the Soviet Union. ${ }^{55}$ But the modernity of the "New Soviet Woman" was deeply ambiguous. If in her dedication to work and upward mobility, gender equality, efficient time management and nationalism, the Stalinist heroine exemplified the modern citizen, her pro-natalism, reliance on sisterhood, and devotion to Stalin was redolent of politics of a pre-modern era.

Stalinism failed to fulfill the ideals of October in that gender parity remained an abstract dream throughout the life of the Soviet Union. The boundaries between the public and the private spheres of existence were not erased as the state failed to institute the welfare utopia it promised. But Stalinism did complete one part of the Bolshevik gender project; it managed to semiotically re-encode the category of "woman" in Soviet public discourse. Officially, Soviet women were never reviled as politically immature or backward, instead, they continued to embody in the abstract the virtues and achievements of the Soviet system.

${ }^{1}$ Martin Malia, “The Hunt for the True October," Commentary, vol. 92, no. 4 (October 1991); "From Under the Rubble, What?" Problems of Communism, Jan/Apr 1992; The Soviet Tragedy (New York, 1994); Michael Holquist, "The Primacy of Politics: Ideology and the Modern Political Practices in the Russian Revolution," Institute for European Studies Working Paper no. 96.2 (June 10, 1996).

${ }^{2}$ Ronald Suny's article offers an excellent account of the paradigm shift from social to cultural history. "Revision and Retreat in the Historiography of 1917: Social History and its Critics," Russian Review, no. 53 (1994), 165-82; See also Sarah Maza, "Stories 
in History: Cultural Narratives in Recent Works in European History," American Historical Review, 101, 5 (1996), 1493-1515, for an analysis of the seminal European works in cultural history.

3 The classics of the totalitarian school of historiography include of course Hannah Arendt's Origins of Totalitarianism (New York 1979); and Carl Friedrich and Zbignew Brzezinski's Totalitarian Dictatorship and Autocracy (Cambridge, Mass. 1956). See also, Adam Ulam, Unfinished Revolution (New York 1960), 198; Donald W. Treadgold, Twentieth-Century Russia (Chicago 1959), 263; Zbigniew Brzezinski, Ideology and Power in Soviet Politics (New York 1967), 42; Peter Kenez, The Birth of the Propaganda State (Cambridge, Mass. 1985).

${ }^{4}$ Bertram Wolfe, An Ideology in Power (New York, 1969), 185.

5 The Bolsheviks were not unique in their desire to civilize the Russian masses. As demonstrated by recent historical research, members of educated Russian society were imbued by a similar aspiration to fundamentally reshape popular culture to fit their own bourgeois aesthetic. See for example, Stephen F. Frank, "Confronting the Domestic Order: Rural Popular Culture and it Enemies in Fin-De-Siecle Russia," in Cultures in Flux: Lower-Class Values, Practices and Resistance in Imperial Russia, Stephen P. Frank and Mark D. Steinberg eds. (Princeton, 1994), 74-107; Joan Neuberger, Crime, Culture, and Power in St.Petersburg, 1900-1914 (Berkeley 1993); Jeffrey Brooks, When Russia Learned to Read: Literacy and Popular Literature, 1861-1917 (Princeton 1985); Katerina Clark, Petersburg, Crucible of Cultural Revolution (Cambridge, Mass. 1995). ${ }^{6} \mathrm{John}$ A. Armstrong, Ideology, Politics, and Government in the Soviet Union (New York 1967), 5 .

${ }^{7}$ Ibid. 39.

${ }^{8}$ Robert V. Daniels, Trotsky, Stalin, and Socialism (Boulder 1991); Also see Russia: The Roots of Confrontation, (Cambridge, Mass. 1985); For a penetrating discussion of Daniels' work see, George Enteen, "Robert V. Daniels's Interpretation Soviet History," Russian Review, vol. 54, no. 3 (July 1995), 315-29.

${ }^{9}$ For citations see footnote no. 1.

${ }^{10}$ David McLellan ed., Karl Marx: Selected Writings (Oxford 1977), 164; H.B. Acton, The Illusion of the Epoch: Marxism-Leninism as a Philosophical Creed (London 1955).

${ }^{11}$ Karl Mannheim, Ideology and Utopia (New York 1960).

12 Nicholas S. Timasheff, The Great Retreat: The Growth and Decline of Communism in Russia (New York 1946).

${ }^{13}$ Richard Stites, Revolutionary Dreams: Utopian Vision and Experimental Life in the Russian Revolution (New York 1989).

${ }^{14}$ Sheila Fitzpatrick, Education and Social Mobility in the Soviet Union, 1921-1934 (New York 1979); Sheila Fitzpatrick ed., Cultural Revolution in Russia, 1928-1931 (Bloomington, Ind. 1978); Sheila Fitzpatrick, The Cultural Front: Power and Culture in Revolutionary Russia (Ithaca 1992); Sheila Fitzpatrick, Stalin's Peasants: Resistance and Survival in the Russian Village after Collectivization (New York 1994); William J. Chase, Society and the Soviet State: Labor and Life in Moscow, 1918-1929 (Urbana, IIl. 1987); Lynne Viola, The Best Sons of the Fatherland: Workers in the Vanguard of Soviet Collectivization (New York 1987).

15 Sheila Fitzpatrick, Everyday Stalinism, (New York 1999); Sheila Fitzpatrick, "How the Mice Buried the Cat: Scenes from the Great Purges of 1937 in the Russian Provinces," The Russian Review, vol. 52, no. 3 (July 1993), 299-320. 


\section{Left History 6.2}

${ }^{16}$ Stephen Kotkin, Magnetic Mountain: Stalinism as Civilization (Berkeley 1995).

17 Ibid. 14.

${ }^{18}$ Clifford Geertz, The Interpretation of Cultures (New York 1973).

${ }^{19}$ Louis Althusser, For Marx, Ben Brewster trans. (Harmondsworth, U.K. 1969).

${ }^{20}$ Ibid. 356.

21 Moshe Lewin, The Making of the Soviet System (London 1985).

22 In an incisive essay, Mikhail Epstein has argued that far from being rigid or stagnant, Soviet ideology is extremely relativistic and "it constantly changes and expands its set of ideas in order that its power remains unchallenged." "Relativistic Patterns in Totalitarian Thinking: An Inquiry into the Language of Soviet Ideology," Kennan Institute Occasional Paper no. 23 (Washington DC 1991), 81. See also After the Future: The Paradoxes of Postmodernism and Contemporary Russian Culture, Anessa MillerPogacar trans. (Amherst, Mass. 1995).

23 This section does not purport to be comprehensive at all and for excellent review essays on the field of women's history see Barbara Alpern Engel, "Women in Russia and the Soviet Union," Signs: Journal of Women in Culture and Society, vol. 12, no. 4 (1987), 781-796; Also Barbara Alpern Engel "Engendering Russia's History: Women in Post-Emancipation Russia and the Soviet Union," Slavic Review, vol. 51, no. 2 (1992), 309-321.

${ }^{24}$ Frederic Jameson, The Political Unconscious (Ithaca 1981), 19.

25 Barbara Evans Clements, Bolshevik Feminist: The Life of Aleksandra Kollontai (Bloomington, Ind. 1979); Beatrice Farnsworth, Aleksandra Kollontai: Socialism, Feminism and the Bolshevik Revolution (Stanford 1980).

26 Wendy Z. Goldman, Women the State and Revolution: Soviet Family Policy and Social Life, 1917-1936 (Cambridge, U.K. 1993).

27 Barbara Evans Clements, "The Birth of the New Soviet Woman," in Bolshevik Culture: Experiment and Order in the Russian Revolution, eds. Abbott Gleason, Peter Kenez, and Richard Stites (Bloomington, Ind. 1985), 220-237. Beatrice Farsnworth, "Bolshevik Alternatives and the Soviet Family: The 1926 Marriage Law Debates," in Women in Russia, Dorothy Atkinson, Alexander Dallin, and Gail W. Lapidus eds. (Stanford 1977), 139-65.

28 Elizabeth A. Wood, The Baba and the Comrade: Gender and Politics in Revolutionary Russia, (Bloomington, Ind. 1997).

${ }^{29}$ Elizabeth Waters, "The Female Form in Soviet Political Iconography, 1917-1932," in Russia's Women: Accommodation, Resistance, Transformation, eds. Barbara Evans Clements, Barbara Alpern Engel, and Christine D. Worobec (Berkeley 1991), 225-242; Frances L. Bernstein "Envisioning Health in Revolutionary Russia: The Politics of Gender in Sexual-Enlightenment Posters of the 1920s," Russian Review, vol. 57, no. 2 (1998), 191-217; Victoria Bonnell, Iconography of Power (Berkeley 1997).

30 "All Stalin's Women: Gender and Power in the Soviet Art of the 1930s," Slavic Review, vol. 57, no. 1 (1998), 172.

${ }^{31}$ See for example, Janet Evans, "The Communist Party of the Soviet Union and the Women's Question: The Case of the 1936 Decree 'In Defense of Mother and Child,"' Journal of Contemporary History 16, 4 (1981), 757-75; Mary Buckley, Women and Ideology in the Soviet Union (Ann Arbor 1989) Goldman agrees with this assessment.

32 Sheila Fitzpatrick, "Middle-Class Values and Soviet Life in the 1930s," in Soviet Society and Culture, Terry Thompson and Richard Sheldon eds., (Boulder 1988), 20- 
38; Roberta Manning, "Women in the Soviet Countryside on the Eve of World War II, 1935-1940," in Russian Peasant Women, Beatrice Farnsworth and Lynne Viola eds., (New York 1992), 206-35.

${ }^{33}$ Richard Stites, The Women's Liberation Movement in Russia: Feminism, Bolshevism and Nihilism, 1860-1930, (Princeton 1978).

34 Nancy Ries, Russian Talk: Culture and Conversation during Perestroika (Ithaca 1997).

35 Alan Dundes uses the term "folk ideas" to describe "the building blocks of worldview." I use ideograms in a similar sense. See his "Folk Ideas as Units of Worldview," in Americo Paredes and Richard Bauman eds., Towards New Perspectives in Folklore (Austin 1972), 93-103.

36 Frederich Engels, The Origins of the Family, Private Property and the State (New York 1972).

${ }^{37}$ See also Karl Marx and Frederich Engels, German Ideology, in Collected Works (New York 1975), for their first attempts to tie the form of the family to the stages of production. Here they argued that the sexual division of labour within the family led to oppression of women.

38 "On the Draft Constitution of the USSR, 1936," Women and Communism (Westport, Ct. 1975), 50. And in his speech in 1925 he argued that "International Women's Day means winning the women's labor reserves to the side of the proletariat," in "Greatest Reserve of the Working Class," ibid., 44.

39 "Labor of Women in the Revolution of the Economy," in Alix Holt ed. and trans. Selected Writings of Alexandra Kollontai (Westport, Ct. 1977), 142-149.

${ }^{40}$ Lenin, in his sparse pronouncements on women's issues, was particularly vicious in his denunciation of domesticity and the deleterious impact it had on women's consciousness. See his speech at The First all-Russian Congress of Women Workers, 19 November, 1918, in Women and Communism (Westport, Ct. 1975) 43. See also his articles, "International Women's Day, 1918," ibid., 46 and "A Great Beginning, June 28, 1919," ibid, 55-57.

41 V.I. Lenin, The Emancipation of Women (New York 1934), 63, 69; Karl Marx and Frederich Engels, Communist Manifesto, (Middlesex, U.K., 1984), 100-101, 105; Leon Trotsky, Women and Family, (New York 1972).

42 Nikolai Bukharin and E. Preobrazhensky, The ABC of Communism (Ann Arbor 1966), 178-79 and 234-235; I. Armand, "Osvobozhdenie ot domashnego rabstva," Kommunisticheskaia partiia $i$ organizatsiia rabotnits. Sbornik statei, rezoliutsii $i$ instruktsii, (Moscow 1919), 31-34.

${ }^{\mathfrak{B}}$ See for example, V. Golubeva, "Trud zhenotdelov v novykh usloviakh," Pravda, 13 April 1923. In a similar trend, the marriage law reform of 1926 stated that parents, rather than the state, should be primarily responsible for the care of the children.

44 L.Trotsky, "Pis'mo tov. Trotskogo," published in G.S.Maliuchenko ed., Mezhdunarodnyi den' rabotnits. Sbornik materialov dlia chtenia i prorabotka v klubakh, izbakh chital'niakh, narodnykh domakh i shkolakh (Rostov-Don 1925), 20-21; GARF fond, 5451, op. 9, d. 526, 1. 1 \& 2, and fond, 5451, op. 14, d. 603, 1.1 \& 2. Central Trade Union reports in GARF from 1921 to 1939 , have extensive references to the necessity of involving women in the improvement of the condition of daily life and the creation/functioning of communal facilities. See my analysis of Woman's Day plays in the NEP era in "Celebrating Women: The International Women's Day in Russia and the 


\section{Left History 6.2}

Soviet Union, 1910-1939" (Ph.D. diss., Indiana University, 1995).

45 "Marxism and the Woman's Movement," in Women in Russia Dorothy Atkinson, Alexander Dallin and Gail Warshofsky Lapidus eds., (Stanford 1977), 91.

46 Alexandra Kollontai, Love of Worker Bees, trans. Cathy Porter (Chicago 1978); Alexandra Kollontay, A Great Love, trans. Lily Lore (Freeport, N.Y. 1971).

47 “Towards a History of the Working Women's Movement in Russia," in Alix Holt ed., Selected Writings of Alexandra Kollontai, 40.

${ }^{48}$ See for example biographical sketches of exemplary Bolshevik women in collections such as, Revoliutsionerki Rossii (Moscow 1983); Slavnye Bol'shevichki (Moscow 1958); Barbara Evans Clements, Bolshevik Women (Cambridge, U.K. 1997).

49 See Zinoviev's speech from 1919, "Rabotnitsa, krest'ianka i sovetskaia vlast"” (Petrograd 1919).

${ }^{50}$ This sentiment had precedent in classical Marxism. According to Marx, paraphrasing Fourier, "the change in a historical epoch can always be determined by women's progress towards freedom, because here, in the relation of woman to man, of the weak to the strong, the victory of human nature over brutality is most evident. The degree of emancipation of woman is the natural measure of general emancipation." Quoted in Lise Vogel, Marxism and the Oppression of Women: Toward a Unitary Theory (New Brunswick, N.J. 1983), 42.

51 Women and Communism, 58.

$\$ 2$ John B. Thompson, op cit., p. 174.

${ }^{53} 1$ have borrowed this notion of ideology as self-understanding of a dominant class rather than a mask that dupes subordinate classes, from J.G.Merquior, The Veil and the Mask (London 1979), 27-29.

54 See for example, Linda Gordon ed. Women, the State and Welfare (Madison 1990); Carole Pattern, The Patriarchal Welfare State: Women and Democracy, Center for European Studies Working Paper Series (Cambridge, U.K. 1987); Seth Coven and Sonya Michel eds. Mothers of a New World: Materialist Politics and the Origins of Welfare States (New York 1993).

55 For an analysis of Stalinist heroines in public propaganda see my article, "Soviet Heroines and Public Identity, 1930-1939," The Carl Beck Papers in Russian and East European Studies no. 1402 (1999), 1-32. 